\title{
Calculation of Economic Rotation Period for Even-Aged Stand in Croatia
}

\section{Stjepan Posavec}

Faculty of Forestry, University of Zagreb Department of Forest Inventory and Management Svetošimunska 25 , 10002 Zagreb, Croatia sposavec@sumfak.hr

\section{Karlo Beljan}

Faculty of Forestry, University of Zagreb Department of Forest Inventory and Management

Svetošimunska 25 , 10002 Zagreb, Croatia

\author{
Silvija Krajter \\ Croatian Forest Research Institute \\ Division for Forest Management \\ and Forestry Economics \\ Trnjanska cesta 35, \\ 10000 Zagreb , Croatia
}

\section{Dario Peršun}

Kontese Nere 23, 10000 Zagreb , Croatia

\section{Abstract}

Background and purpose: Even-aged forests prevail in Croatia's forestry. Rotation period is based mostly on natural parameters. In practice, rotation period is given by Croatian Rulebook of forest management. Cutting age is determined based on inventory data and many other stand characteristics. Rotation period is a planned time and it always has to be unique for particular tree species, and cutting age is the age of a stand at the moment of the final cut. The aim of the paper is to compare rotation period based on economic parameters and rotation period determined by using forest inventory data.

Material and methods: Owing to absence of long term stand calculation data, research object was taken from Forest Management Handbook (1995). Mean annual increment (MAl) and current annual increment (CAI) provided fundamental data for calculations. The research was conducted at one hectare Common Beech (Fagus sylvatica L.) stand. Assortment structure and value of timber was estimated by the present cutting value method calculated by using Croatian forests Ltd. Price list for the year 2008. Labor costs in forest exploitation were also taken into account.

Results and conclusion: In order to achieve cost-effective management of common beech stands, it is necessary to adjust current optimal rotation period. Optimal rotation period should be based on management goals as the main factors. So far the most common criterion adopted in Croatian forestry has been the rotation of maximum sustained yield or maximum Mean annual increment. The presented results indicate that common forest management practice should be changed in order to achieve cost-effective management of beech stands in the future.

Keywords: forest economics, economic rotation period, even-aged forests, common beech (Fagus sylvatica L.)

\section{INTRODUCTION}

One of the fundamental questions in forest economics is when is the best time to harvest a forest stand. Forest rotation period is a question of economic goal and an essential basis of long-term planning in forestry all together, but also in individual units of administration and management such as forest management areas, forest industry and forestry [1]. Rotation period represents the number of years which have passed between the establishment of the stand and its final harvesting at the end of regeneration period.

After achieving the management goal the cutting of all trees in the same area occurs and stand regeneration begins. The optimal rotation refers to optimal time for final harvesting (clear-cutting).

The main issue in optimal rotation is choosing the optimal time for final harvesting, followed by reforestation and another even-aged stand. In economics, these kinds of decisions in general should be made based on the forest owner's optimization behavior. Therefore, forest owner should first specify the target (or actually choose among three alternative targets): (1) maximum sustained yield, (2) forest rent or (3) land rent that a forest owner tries to maximize [2].

The debate on the appropriate criteria for determining the optimal forest rotation is a long-lasting one [35]. The most common criteria [6] adopted in forestry is the rotation when stand achieves maximum sustained yield or maximum mean annual increment.

The minimal rotation period for even-aged stands is prescribed by the Rulebook of forest management [7]. For protective forests and forests with special 
purpose rotation is usually based on physiological maturity of the trees. In uneven aged forests cutting age for forest trees is based on tree diameter and cutting maturity, i.e. the optimal diameter of the tree; when the tree is mature enough to be harvested. Cutting maturity means that the age when net present value of forest is maximized whereas value may include timber and non-timber values. This statement refers to mature timber, and not to old growth and thinning [8]. The volume of wood to be cut should take into account the demand of the market, but also the capacity of the forest, whereas there is a need to take into account production capabilities, along with maintaining or increasing forest stock [9]. Determining economically the most advantageous rotation period is an investment problem as well as a forest (management) inventory problem associated with particular land use [10].

Economic rotation of forest stand is achieved when the maximum income is reached, i.e., when the most valuable timber stocks are produced. Increase in the value of growing stock is more stable than the increment value. Maximum growth value occurs after the maximum of the timber value increment. Age of economic maturity can be determined by using the tangent drawn from the origin of coordinate system on the curve value of growing stock or determine the age where the highest possible income would be achieved by calculation.

In even-aged forests economic maturity results in a very long rotation, especially for those tree species whose price increases proportionately with age. In case of Pedunculate oak (Quercus robur L.) forest the value increases in correlation with the cube of diameter at breast height [11]. As the diameter of elite trees increases, the value increases as well or remains constant. This means that Pedunculate oak trees should not be cut as long as they are healthy and their value is constantly increasing.

In order to ensure sustainable income from a forest there is a need to find the answer to how, where and when timber should be cut in a forest and how the stand would be regenerated. Sustainable yield will be acchieved if the forest has not been cut more than its annual growth increment.

In this paper we are analyzing whether it is possible to determine economic rotation for even-aged forest based on natural and economical parameters. Comparison between the rotation period used in Croatian forestry practice and economic rotation period was made.

\section{MATERIAL AND METHODS}

Common beech (Fagus sylvatica L.) is the most common tree species in Croatia, spreading over 744796 ha. It takes the highest proportion in the Croatian growing stock (36\%) [12].
Beech forests are classified according to the management of forest types for the economic production of quality logs (veneer logs, peeling logs and sawing) and wood for chemical processing. Even-aged management system always gives better round wood than the selective one.

Because of the long production (and rotation) period product prices are affected by inflation. Prices of timber assortments and labor price are not equal throughout the production period (100 years in this case) and it is difficult to calculate them precisely. Due to various limitations of long term calculation the assumption of constant prices for products, silvicultural and administrative costs have been used. In calculation, inflation will be zero. Thus, the average costs and prices for goods and services will be constant over time.

The subjects of the research are 14 common beech stands size of one hectare, one per decade. Research stands are on first site quality-class managed with even-aged management system. The data source was Forest Management Handbook from which data on development of growing stock, current annual increment (CAI) and mean annual increment (MAI) from stand establishment until the end of the rotation (Table 1) were taken.

Yield tables are used for comparison of real growing stock status in a real forest under normal conditions. The calculation is made on the basis of an established tariff sequence obtained from double-entry tree volume tables and a height curve. Diameters at breast height were measured by total callipering. In the evenaged stands that are allocated for felling in the following ten years, all trees were measured.

\section{TABLE 1}

Stand characteristics (CAl- Current Annual Increment, MAl- Mean Annual Increment) [13]

\begin{tabular}{|c|c|c|c|}
\hline Age & $\begin{array}{c}\text { Stand } \\
\text { volume } \\
\left(\mathrm{m}^{3} / \mathrm{ha}\right)\end{array}$ & $\begin{array}{c}\text { Current annual } \\
\text { increment } \\
\left(\mathrm{m}^{3} / \mathrm{ha} / \text { year }\right)\end{array}$ & $\begin{array}{c}\text { Mean annual } \\
\text { increment } \\
\left(\mathrm{m}^{3} / \text { ha/year }\right)\end{array}$ \\
\hline 20 & 100 & 12.0 & 5.5 \\
\hline 30 & 185 & 13.0 & 7.7 \\
\hline 40 & 254 & 13.3 & 9.0 \\
\hline 50 & 310 & 13.9 & 9.9 \\
\hline 60 & 367 & 13.1 & 10.5 \\
\hline 70 & 419 & 12.4 & 10.9 \\
\hline 80 & 469 & 11.6 & 11.1 \\
\hline 90 & 516 & 10.5 & 11.1 \\
\hline 100 & 557 & 9.4 & 11.1 \\
\hline 110 & 591 & 8.6 & 10.9 \\
\hline 120 & 618 & 7.8 & 10.7 \\
\hline 130 & 637 & 6.7 & 10.5 \\
\hline 140 & 646 & 6.6 & 10.2 \\
\hline 150 & 654 & & 10.0 \\
\hline
\end{tabular}


For more accurate estimation of wood value data for wood above $3 \mathrm{~cm}$ was used. By using the CAl and MAI data (natural indicators) minimum rotation period is determined. Minimum rotation period was defined when the CAI and MAI were equal. In this case it is at the age of 85 years. Rotation period should not be shorter than prescribed, but it is allowed, in particular circumstances, to make the final cut before planned rotation period is reached. In Croatia prescribed rotation period for evenaged Common beech stands is 100 years.

Even though determined minimum rotation period is 85 years, stand will be cut much later. The reason for that lies in the fact that other forest services apart from timber are important too, as well as increased value of timber if the cutting is postponed.

\section{The present cutting value method}

The economic value of forest can be calculated from the selling prices of the timber assortments. In this method of determining the economic value, forest is considered as a final product that can be cut and sold immediately. Consequently, this method is often recognized in literature [11] as value of forest stand which is cut and sold at any age. To determine the value of the stand based on the amount of its assortments it is necessary to take prices of assortments. Content of assortments must be multiplied by current price. Obtained result is the market value of the stand. This value is very low for young stands and it grows with age of the stand.

\section{Economic rotation period}

Economic rotation period is achieved when the maximum profit is reached (maximum forest rent), i.e. when the stand produces the most valuable timber stocks. Increment of growing stock value is more stable than growing stock volume. Maximum growth of value occurs after the maximum growing stock increment volume. According to the equation by the $[9,11,14]$ forest rent $(r)$ is:

\section{TABLE 2}

Forest coverage in Croatia (source [8])

\begin{tabular}{|c|c|c|c|c|c|c|}
\hline Age & $\begin{array}{c}\text { Growing } \\
\text { stock }\left(\mathrm{m}^{3}\right)\end{array}$ & $\begin{array}{c}\text { Stand Value } \\
\text { (EUR) }\end{array}$ & $\begin{array}{c}\text { Thinning } \\
\text { Value (EUR) }\end{array}$ & $\begin{array}{c}\text { Silvicultural } \\
\text { costs (EUR/ha) }\end{array}$ & $\begin{array}{c}\text { Administrative } \\
\text { costs (EUR/ha) }\end{array}$ & Net Value (EUR) \\
\hline 20 & 100.00 & 1882.88 & 610.52 & 248.63 & 62.16 & 2182.61 \\
\hline 30 & 185.00 & 3483.33 & 1064.05 & 433.33 & 108.33 & 4005.72 \\
\hline 40 & 254.00 & 4782.51 & 1449.82 & 590.43 & 147.61 & 5494.29 \\
\hline 50 & 310.00 & 5836.93 & 1543.96 & 628.77 & 157.19 & 6594.93 \\
\hline 60 & 367.00 & 6910.17 & 1487.47 & 565.07 & 141.27 & 7691.30 \\
\hline 70 & 419.00 & 8167.94 & 1442.55 & 548.00 & 137.00 & 8925.48 \\
\hline 80 & 469.00 & 9142.64 & 1345.08 & 510.98 & 127.74 & 9848.99 \\
\hline 90 & 516.00 & 10058.85 & 1247.61 & 450.81 & 112.70 & 10742.94 \\
\hline 100 & 557.00 & 10858.10 & 1169.63 & 422.64 & 105.66 & 11499.44 \\
\hline 110 & 591.00 & 11608.81 & 1158.92 & 336.00 & 84.00 & 12347.73 \\
\hline 120 & 618.00 & 12139.16 & 1158.92 & 336.00 & 84.00 & 12878.08 \\
\hline 130 & 637.00 & 12512.37 & 1139.27 & 211.92 & 52.98 & 13386.75 \\
\hline 140 & 646.00 & 12689.16 & 1139.27 & 393.64 & 98.41 & 13336.38 \\
\hline 150 & 654.00 & 12846.30 & & & & \\
\hline
\end{tabular}

Where is: $(A u)$ growing stock value in u-year stand, $\left(\sum D\right)$ sum of values from thinning, (c) silvicultural cost, (v) the administrative cost per unit area, $(u)$ forest size in hectares.

The formula gives the annual forest rent per unit area, assuming sustainable forest management. Silvicultural and administrative costs culminate at the same time as the forest rent.

\section{RESULTS}

To estimate current value of forest stands the method of the present cut value is used. Using data of growing stock with assortment tables and price lists, classification by age and worth is made. The estimated economic value of the existing growing stock and economic value of assortments harvested in thinning is presented in Table 2.

Stand value grows continuously over time. Thinning values start decreasing after the age of 60 . This is due to the positive selection (as one of the causes), where we cut the low value trees after the half of the rotation period. The best quality trees wait for the end of rotation period to be cut.

By using the equation (1) net value is calculated for the period between age 20 and age 150. The stand and thinning volume was estimated by present cutting value method (using assortment tables and stumpage price from Croatian forest Itd. for year 2008). Silvicultural costs are calculated by Labor Price List [15] of Croatian Forests Ltd. Administrative costs ( $v$ ) were estimated at $25 \%$ of total silvicultural (biological reproduction) costs [16]. Net value is a result of forest rent, which is generated through sales of timber assortments [17]. 
Economic rotation is the rotation period of time when the highest net value is realized. Net value increases since the establishment of the stand, and reaches its maximum at the age of 130 years. The most important factors affecting the net value are silvicultural costs, administration costs and economic value of assortments harvested in thinning.

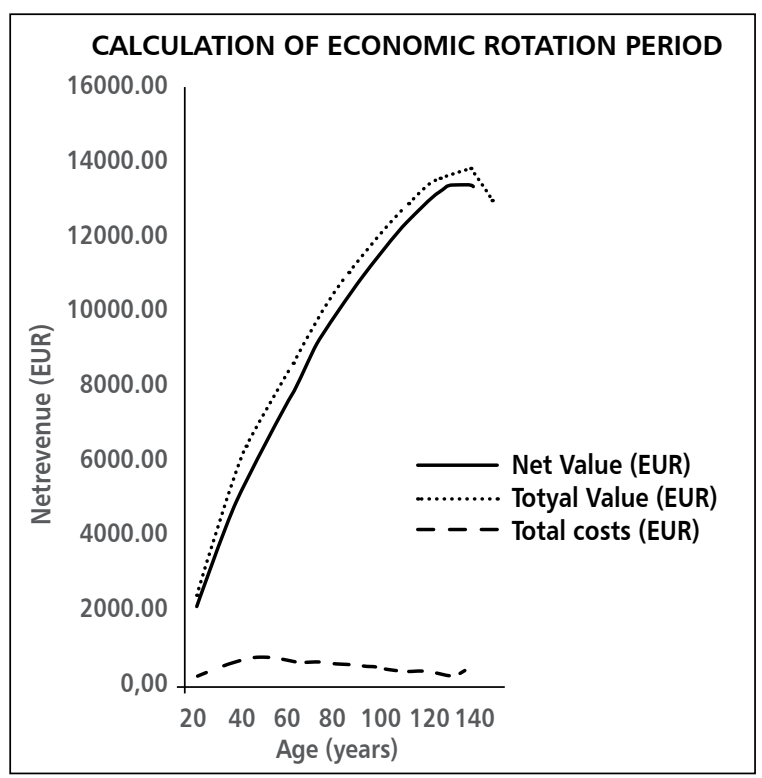

FIGURE 1

The highest net value

According to the calculation of the main parameters for value (stand value and thinning value) and forest management costs (silvicultural costs and administrative costs) from Table 2 and Figure 1, achieved economic rotation is highest at the age of 130 years with the amount of 13386.75 EUR net revenue.

\section{CONCLUSIONS}

Determining total value of forests, as well as values of certain functions is necessary for efficient management of natural resources and quality of decisions in forestry [11]. For valuation of forest stand according to various biological parameters different methods exist [18].

A rotation period starts with establishment of the forest stand and finishes after several decades, when most of the trees are harvested and regeneration of the forest stand is achieved. During the rotation period silvicultural activities generate forest management costs.

From the production point of view, the fact that both trees and forests can produce different goods and services at the same time is an advantage but poses also complex management problems.

For the research purpose timber production was the only management goal (non timber values were ignored). Thus, we have analyzed only one decision, the optimal economic rotation, by which forest owner can control profitability of timber production.

In order to achieve cost-effective management of beech stands, it is necessary to adjust the optimal rotation period. On beech stands in Croatia which are managed with even-aged management system the planned rotation of 100 years is applied. From economic point of view, this is not always acceptable and it is necessary sometimes to extend the rotation period by 30 years (as in this case), depending on the stand conditions. One of many reasons for cutting age not being much higher than 100 years is false beech heartwood affecting the quality of beech logs [19].

The optimal forest rotation is influenced by productivity (quality) of the land, the value of the timber produced, the harvesting costs, taxes and administration costs, forest interest rate and non-timber forest products and services. They vary widely in different circumstances. Timber prices and harvesting costs are most unpredictable variables due to the long production period in even-aged forests. Adding nonmonetary benefits derived from standing timber will lengthen the optimal rotation.

For more accurate calculation of rotation period it is necessary to carry out further research on different stands.

\section{REFERENCES}

1. SABADI R 1985 Prilog raspravi o dužini ophodnje u šumama hrasta. Šum list 109 (1-2):7-15

2. SAASTAMOINEN O, MATERO J 2006 Introduction to forestry, forest policy and economics. European Forest Institute - University of Joensuu. p 95

3. MÖHRING B 2001 The German struggle between the 'Bodenreinertragslehre' (lant rent theory) and 'Waldreinertragslehre' (theory of the highest revenue) belongs to the past - but what is left? For Policy Econ 2 (2):195-201.

4. HYYTIÄINEN K, TAHVONEN O 2003 Maximum sustained yield, forest rent or Faustmann: does it really matter? Scand J Forest Res 18: 57-469.
5. VIITALA E-J 2006 An early contribution of Martin Faustmann to natural resource economics. J Forest Economics 12 (2):131-144.

6. NAUTIYAL JC 1988 Forest Economics. Principles and Applications. Canadian Scholars' Press Inc. Toronto, p 581

7. THE MINISTRY OF AGRICULTURE, FORESTRY AND WATER MANAGEMENT 2006 Regulation on forest management. Official Gazette, zagreb, 111

8. KLEMPERER DW 2003 Forest Resource Economics and Finance. Virginia Polytechnic Institute and State University Collage of Natural Resource, p 551 
9. KLEPAC D 1965 Uređivanje šuma. Školska knjiga, Zagreb, p 341

10. ZHANG D, PEARSE P 2011 Forest economics. UBC press, Vancouver, Toronto, p 390

11. FIGURIĆ M 1996 Uvod u ekonomiku šumskih resursa. Šumarski fakultet, Sveučilišta u Zagrebu, p 244

12. ČAVLOVIĆ J 2010 Prva nacionalna inventura šuma Republike Hrvatske. Ministarstvo regionalnog razvoja, šumarstva i vodnog gospodarstva, p 300

13. MEŠTROVIĆ Š, FABIJANIĆ G 1995 Priručnik za uređivanje šuma. Hrvatske šume d.o.o., Ministarstvo poljoprivrede i šumarstva, p 416

14. NENADIĆ Đ. 1922 Računanje vrijednosti šuma i šumska statika. Hrvatsko šumarsko društvo, Zagreb, p 422

15. CROATIAN FORESTS LTD. 2008 Interne prodajne cijene usluge radnika, strojeva i vozila. Hrvatske šume d. o. o. Zagreb

16. POSAVEC S, ZELIĆ J, FLISZAR I, BELAN K 2011 Implementation of Cost Calculation Model in Forest Evaluation of Požega Forest Administration. Croat J For Eng 32 (1): 457-467

17. CROATIAN FORESTS LTD. 2008 Cjenik glavnih šumskih proizvoda, Hrvatske šume d.o.o., p 32

18. POSAVEC S, ŠEGOTIĆ K, ČAKLOVIĆ L 2006 Selection of biological parameters in valuation of natural resources. Periodicum biol 108 (6): 671-676

19. PRKA M, ZEČIĆ Ž, KRPAN A P B, VUSIĆ D 2009 Characteristic and Share of European Beech False Heartwood in Felling Sites of Central Croatia, Croat J For Eng 30 (1): $37-49$ 